\title{
ANALISIS DETERMINAN FAKTOR PENYEBAB UMKM NAIK KELAS DI ERA PANDEMI COVID 19
}

\author{
Dingot Hamonangan Ismail Sitanggang \\ Politeknik LP3I Jakarta \\ visiaulia@gmail.comdan ismail@plj.ac.id
}

\begin{abstract}
Abstrak.
Peran UMKM dalam menyelamatkan ekonomi bangsa tidak dapat diragukan lagi. Dari krisis tahun 1997 dan juga saat krisis 2020 sebagai akibat dari pandemic covid 19. Dalam pandemi covid 19 cukup banyak UMKM yang bermasalah. Penelitian terhadap UMKM selama periode Covid 19 sejak Desember 2019 sampai saat ini Oktober 2020, dengan menggunakan studi pustaka menunjukkan bahwa diantara penyebab UMKM naik kelas semasa covid 19 adalah karena UMKM tersebut dengan kelincahannya menyesuaikan diri dengan tuntutan perubahan kebutuhan perilaku konsumen pada satu sisi dan pada sisi lainnya selalu melakukan inovasi produk, inovasi pelayanan sesuai persepsi konsumen seperti dengan memperbaiki kemasan, menerapkan protocol covid dalam produksi, pelayanan antara jemput, berpromosi secara on line serta bersedia melakukan pembayaran di tempat ( OCD). Saran dari penelitian ini adalah perlu dilakukan penelitian lebih lanjut dengan sampel yang lebih luas dan beragam jenis usahanya.
\end{abstract}

Kata kunci: UMKM Naik Kelas, Covid 19, Inovasi Usaha, Digital Marketing

\begin{abstract}
.
The role of small and medium bussness enterprises in saving the nation's economy cannot be doubted. From the 1997 crisis and also during the 2020 crisis as a result of the Covid 19 pandemic. In the Covid 19 pandemic, quite a number of small and medium enterprises had problems. Research on small and medium enterprises during the Covid 19 period from December 2019 to October 2020, using a literature study shows that among the reasons for small and medium enterprises to upgrade during covid 19 is because these small and medium enterprises with their agility adjust to the demands of changing consumer behavior needs on the one hand and on the one hand. others always make product innovations, service innovations according to consumer perceptions such as by improving packaging, implementing the Covid protocol in production, providing shuttle services, promoting online and being willing to make payments on the spot $(O C D)$. The suggestion from this research is that further research is needed with a wider sample and various types of business.
\end{abstract}

Keywords: Small and medium enterprises, Covid 19, Business Innovation, Digital Marketing

\section{PENDAHULUAN}

Peran UMKM bagi ketahanan ekonomi bangsa sudah tidak diragukan lagi. Ketika krisis ekonomi tahun 1998 menerpa Indonesia, UMKM hadir sebagai penyelamat. Peran serupa dimainkan UMKM pada tahun 2019 akhir - saat krisis ekonomi akibat pandemic covid 19 kembali melanda dunia, sehingga banyak perusahaan besar gulung tikar dan melakukan pemutusan hubungan kerja. Demikian juga sekitar $85 \%$ juga mengalami masalah. Namun dengan tubuh langsingnya dan juga karena UMKM tidak punya pilihan lainnya beradaftasi atau punah, terbuki UMKM ada yang sukses bahkan naik kelas selama pandemic covid 19. Itulah teladan yang bisa ditiru dari pelaku UMKM naik kelas tersebut. 
"Tidak ada satupun negara yang dapat memprediksi kapan pandemi COVID-19 ini akan berakhir. Cara sederhana beradaptasi dan menghadapi pandemi ini adalah dengan menyiapkan strategi-strategi jangka pendek dan jangka panjang sambil terus berharap vaksin virus COVID-19 segera ditemukan dan diproduksi massal. Kebijakan jangka pendek yang dapat diterapkan adalah bantuan keuangan baik dalam bentuk pinjaman lunak atau bantuan tunai langsung dengan melibatkan pemerintah dan sektor swasta. Sementara strategi jangka panjang difokuskan pada pengenalan dan penggunaan teknologi digital bagi UMKM sekaligus persiapan untuk memasuki era Industri 4.0." Ujar Aknolt Kristian PakpahanKompas 2020).

UMKM bukan tanpa masalah di masa covid. Mereka juga memiliki sejumlah masalah sebagaimana dialami jenis usaha lainnya. Yang membedakan UMKM dengan usaha lainnya adalah bahwa UMKM tidak punya pilihan lain. Pilihannya terus bergerak untuk tetap eksis atau berhenti dengan resiko kehilangan tabungan dan bahkan segalanya. "Kini UMKM di Indonesia tengah menghadapi tantangan baru. Pandemi COVID-19 telah berdampak secara signifikan pada UMKM di Indonesia. Dalam survey yang dilakukan oleh Micro Mentor Indonesia terhadap 250 pengguna UMKM, tercatat bahwa 67\% pendapatan UMKM menurun, 10\% UMKM kesulitan memperoleh bahan baku, dan 5\% UMKM mengalami ketidakstabilan cash-flow. ( MicroMentor Indonesia”Maret 2020 ) Berdasarkan Business Outcome Survey, Maret 2020 yang dilakukan MicroMentor Indonesia terhadap 182 UMKM pengguna aktif). Artinya sebagai mana usaha besar yang mengalami guncangan saat krisis, UMKM juga mengalaminya. Tetapi ada sedikit UMKM yang dengan lincahnya melalukan maneuver dengan cerdas sehingga segera recovery dan bahkan sukses berselancar dengan gelombang covi 19 dan bahkan naik kelas.

Penelitian ini tidak akan membahas tentang problematika UMKM. Sebaliknya riset ini akan fokus melihat UMKM naik kelas. Studi tentang UMKM Naik kelas dimasa normal juga sudah banyak dilakukan. Lebih spesifik lagi penelitian ini akan melihat bagaimana UMKM beradaftasi dengan perubahan sehingga bisa naik kelas. Beberapa studi tentang penyebab UMKM sudah dilakukan ( Euis Winarti, D. Purnomo, Jaenudin (2019), Ratna Maulidiyah, Siti Saroh, Ratna Niken Hardati (2020), . Tetapi studi tentang penyebab UMKM dimasa covid relative belum banyak tersedia kecuali berupa ulasan singkat dan parsial menyororoti dimensi sisi perubahan perilaku konsumen dan adaftasi terhadap perubahan baru ( covid dan trend digitalitasi UMKM ) Dominica A. Widyastuti (2020), dan model pembayaran non cash ( Didik Haryadi Santoso (editor ) Juni 2020,

Penelitian ini akan melihat apa saja faktor determinan dari pada penyebab suksesnya atau naik kelas UMKM di masa pandemic covid 19 yang kebetulan momentumnya bertepatan dengan revolusi Industri dan juga lahirnya generasi Z, agar bisa ditemukan apa sesungguhnya faktor determinan penyebab UMKM naik kelas dimasa pandemic covid 19.

\section{METODE PENELITIAN}

Metodologi Penelitian Penelitian ini menggunakan pendekatan eksploratif deskriptif dengan menganalisis strategi UMKM naik kelas di masa covid 19. Karya ilmiah ini juga dikembangkan dengan menggunakan pendekatan kajian literatur atau studi putaka. Pendekatan teori/konsep dilakukan dengan merujuk dari beberapa sumber, seperti buku, 
jurnal ilmiah, dan internet. Semua uraian gagasan yang ada digabungkan dalam satu susunan kerangka pemikiran.

\section{HASIL DAN PEMBAHASAN}

Secara sederhana UMKM diartikan sebagai jenis usaha paling rendah. Seorang pengusaha pemula dan baru mendirikan usaha dengan modal apa adanya dimasukkan pada kategori usaha mikrokecil dan menengah. Jadi baik dari segi jumlah kekayaan ataupun jumlah tenaga kerja, UMKM merupakan jenis usaha paling kecil ukurannya juga jumlah assetnya. Karena itu di masa Pandemic covid 19, UMKM merupakan jenis usaha yang paling mengalami msasalah. Ascarya Rahmawati, Siti (2015), mengutip Badan Pusat Statistik mendefinisikan UMKM menurut jumlah tenaga kerja. Usaha yang mempekerjakan kurang dari 5 tenaga kerja dikategorikan sebagai UM, UK memiliki 5 hingga 19 tenaga kerja, sedangkan usaha menengah memiliki 20 hingga 99 tenaga kerja. Klasifikasi itu didasarkan pada jumlah tenaga kerja tanpa memperhatikan aset total maupun penjualan tahunan. UU UMKM No. 28/2008 mengklasifikasi UM berdasarkan aset dan penjualan tahunan, sebagaimana ditunjukkan dalam

Tabel 1. Jenis Usaha Mikro Kecil Menengah

\begin{tabular}{lc}
\hline Jenis Usaha & Kriteria (UU UMKM No.20/2008) \\
\hline Mikro & - Aset $<50$ juta rupiah (tidak termasuk properti) \\
& - Penjualan tahunan $<300$ juta rupiah \\
\hline Kecil & -Aset 50 juta-500 juta rupiah (tidak termasuk properti) \\
& -Penjualan tahunan 200 juta-2,5 miliar rupiah \\
& - Aset 500 juta-10 miliar rupiah \\
Menengah & \\
\hline
\end{tabular}

\section{Faktor Penyebab UMKM Naik Kelas}

UMKM dari segi ukurannya memang kecil, tetapi dari segi jumlah ia sangat besar sehingga bagaikan raksasa tidur yang mendominasi perekonomian Indonesia. Berdasarkan data Bank Indonesia (2012) sebanyak 99.99\% unit dari keseluruhan pelaku bisnis nasional; atau sebanyak 56,5 juta unit. Dengan kemampuan penyerapan tenaga kerja sebanyak 107,7 juta orang atau 97.2\%. Dan memberikan kontribusi pada PDB sebesar 57.9\%dan ekspor non-migas sebasar 14\%. ( Wilantara, halaman 28 ).

Karena besarnya jumlah pelaku UMKM tersebutlah maka pemerintah memberikan karpet merah bagi UMKM agar dapat naik kelas menjadi usaha menengah dan menjadi usaha besar, 
Namun usaha tersebut tetap kandas ditempat disebabkan sejumlah kendala yang melekat di dalam dirinya. Menurut CEO Smartplus Consulting, Yuszak M Yahya (2014) sebagaimana dikutip Wilantara, Lebih dari 60 persen masalah UMKM itu terkait dengan problem internal yaitu knowledge (pengetahuan). Itu pula yang jadi problem UMKM untuk berdinamika dengan era Information Society dan Knowledge Base Society yang menempatkan "knowledge" menjadi sumber daya yang lebih "powerful" dibandingkan kapital dan sumberdaya alam saat ini.

Sedangkan hambatan UMKM dari sisi ekternal adalah adalah terkait dengan akses a).Pembiayaan usaha yang terbatas, (b) mahalnya biaya infrastruktur, dan (c) layanan birokrasi yang tidak efisien. Sedangkan masalah internal, yakni (a) kelembagaan dan SDM, (b) pemasaran, dan teknologi, (c) modal intelektual. Masalah eksternal membutuhkan usaha aktif dari pemerintah dan lembaga keuangan untuk mengatasinya. Sedang masalah internal bersumber dari lemahnya modal intelektual di kalangan UMKM. ( Wilantara: halaman 54 ).

\section{UMKM Naik Kelas}

Dengan demikian, upaya memberdayakan UMKM selain mengatasi problem internal UMKM adalah menyediakan stimulus eksternal lainnya yang membuat UMKM bisa naik kelas.

Ascarya Rahmawati, Siti (2015), mengutip pendapat Jasra et al. (2011) mengemukakan bahwa faktor kunci kesuksesan dari UKM adalah sumber keuangan, strategi pemasaran, teknologi, dukungan pemerintah, akses informasi, perencanaan usaha, dan keterampilan wirausahawan. Elfahmi, Suryono Hadi Jatmika, Dodik (2019), secara khusus menyoroti Pengaruh Inovasi Terhadap Ukm Naik Kelas Melalui Daya Saing Produk dalam penelitiannya terhadap 150 orang pelaku UMKM. Hasil penelitian menyatakan bahwa inovasi produk berpengaruh terhadap daya saing UKM naik kelas Karena omset UKM naik kelas melalui produk yang berdaya saing.

Pandangan berberda disampaiakan Martomo, Z I Liquiddanu, E Sutopo, W (2018) yang melihat UMKM secara lebih komprehensif. Dalam penelitiannya Pada Industri Kecil Menengah (IKM) di Kota Surakarta mengatakan Terdapat lima dimensi untuk penilaian pertumbuhan IKM yaitu dimensi entrepreneur orientation, motivasi pengusaha, tahapan perusahaan, sumber daya perusahaan dan lingkungan perusahaan.

"....., dimana dimensi entrepreneur orientation terdapat empat elemen yaitu inovasi, proaktif, mengambil resiko dan agresifitas kompetitif, dimensi motivasi terdapat dua elemen yaitu motivasi ekstrinsik dan motivasi intrinsik, dimensi tahapan perusahaan terdapat dua elemen yaitu kontekstual dan struktur, dimensi sumber daya perusahaan terdapat empat elemen yaitu karakteristik pengusaha, sumber daya internal, hubungan dengan pemasok dan hubungan dengan perlanggan, dimen lingkungan perusahaan terdapat tiga elemen yaitu peranan KUBE, peranan pemerintah dan pengaruh lingkungan” tegasnya.

Pandangan Martomo selaras dengan pandangan dan Brad Sugars yang melihat faktor SDM dan Faktor tata kelola organisasi UMKM sebagai dua sisi mata uang dari naik kelas suatu usaha. Artinya, kecermelangan seorang pengusaha merupakan faktor penting bagi berkembangnya suatu usaha, namun jika ingin naik kelas, maka perusahaan tersebut juga harus membangun tata kelola organisasi sesuai dengan tingkatannya. Pandangan senada disampaikan Bradley Sugar. Agar UMKM naik kelas perlu penataan secara sistemik UMKM 
tersebut baik dari sisi manajemen maupun sisi SDM seperti dikatakan Pakar SDM dunia Dave Ulrich dan juga motivator Malasya. Bradley Sugar lebih lanjut mengatakan apa yang harus dilakukan usaha mikro kecil agar naik kelas menjadi usaha menengah dan besar adalah

1. Perusahaan harus menjadi organisasi pembelajar dan pintar beradaftasi dengan perubahan seperti dikatakan oleh Dingot Hamonangan Ismail ( 2016 ) sehingga senantiasa belajar dengan perubahan dan menyesuaikan gerak dinamika organsiasi dengan kebutuhan konsumen yang terus berubah yang ditandai dengan warga dan organisasi pembelajar.

2. Tata kelola yang bagus termasuk Manajemen Pembukuan keuangan yang baik dan benar

\section{Faktor determinan dari pada penyebab UMKM Naik kelas dimasa pandemic covid 19}

a. Digital Marketing sebagai solusi di Era Vandemic Covid

Ramaditya, Muhammad Effendi, Syahrul Faruqi, Faris Darmawan, Arya (2020), dalam studinya terhadap UMKM Di Wilayah Rawamangun mengatakan saat Indonesia kini memasuki era industry 4.0, maka pemanfaatan sarana teknologi, informasi dan komunikasi dalam melakukan perdagangan secara elektronik adalah keharusan yang dilakukan oleh para pengusaha mikro, kecil dan menengah (UMKM) dalam upaya meningkatkan omset penjualan dan memberikan nilai lebih kepada konsumen. Pandangan senada disampaikan Ratnadianti, Aulia Fahmi, Idqan Hannan, Sufrin (2020), Digital Marketing Strategy of Small and Medium Enterprises for Snack in Bogor City secara khusus Penelitiannya menghasilkan sebelas rekomendasi strategi pemasaran digital, yaitu peningkatan daya tahan produk makanan ringan, menyediakan variasi rasa produk yang beragam, mendesain tampilan kemasan dan merek yang menarik, mencantumkan informasi nilai gizi produk, menetapkan harga yang terjangkau, menggunakan media informasi yang tepat, memilih media promosi yang tepat, memberikan promosi yang menarik bagi konsumen, menampilkan testimonial konsumen, menampilkan gambar dan deskripsi produk yang jujur, dan menyediakan berbagai jenis alat pembayaran. Saprianto, Febi (2020), Dilematis Umkm Di Era Digital mengatakan bahwa Peluang UMKM di era digital telah menempatkan posisi UMKM setara dengan korporasi, bahkan dengan pesaing luar negeri. Mengingat pasar di era digital melibatkan warga dunia, tidak hanya Indonesia. Selain itu, banyak perusahaan internasional yang membuka diri untuk melakukan kerja sama dengan pelaku usaha lokal dengan tujuan agar dapat menjangkau penjuru dunia, sehingga dimungkinkan saling memberikan keuntungan. Apalagi dalam situasi pandemic covid 19 dimana konsumen takut keluar rumah, mereka lebi h nyaman di layani oleh pelaku UMKM yang siap antar jemput seperti gofood dan lain sebagainya.

Padangan senada disampaikan Ali Minanto, Mutia Dewi, Puji Hariyanti (239) ia mengatakan Didik Haryadi Santoso (2020) bahwa wabah covid-19 ini seolah memaksa dan mempercepat semua unit usaha untuk bisa beradaptasi dan mulai menggunakan internet untuk operasional usahanya. Kebiasaan belanja konsumen dari cara offline menjadi online di tengah wabah ini semakin memperkuat pergeseran itu. Menurutnya agar UMKM sukses naik kelas harus bisa memproduksi konten-konten kreatif seperti video pendek, e-poster, katalog virtual dan pesan- pesan menarik lainnya yang dikemas secara visual. Konten-konten visual tersebut memudahkan UMKM untuk menyebarluaskannya melalui aplikasi social media seperti whatsapp, Instagram dan facebook

\section{b. Metode pembayaran OCB}


Termasuk dalam hal penyebab UMKM naik kelas adalah kemampuan UMKM melakukan pembayaran secara on line dan OCD. Sehingga konsumen yang malas ke luar rumah bisa membayar di lokasi setelah barang tiba. Hal ini selain menambah kepercayaan konsumen dan juga sangat potensial untuk menanbahkan pelanggan baru.

c. Penggunaaan Protokol Kesehatan

Menurut Arief Nuryana dalam Didik Haryadi Santoso (2020) salah hal yang perlu dilatihkan kepada UMKM saat Covid saat ini adalah dalam studinya di Surakarta adalah bagaimana para pelaku UMKM dilatihkan program Kesehatan yang meliputi: Program Pelatihan Hiegine dan Sanitasi, Program Sosialisasi Protokeler Kesehatan, dan Program Bantuan Sarana sehingga UMKM dapat melayani masyarakat yang sangat peduli dengan kesehatan dan takut tertular virus Covid.

d. Melaksanakan inovasi produk sesuai kebutuhan Konsumen

Menurut Errol Rakhmad Noordam, M.Farm.,Apt h.209 dalam Didik Haryadi Santoso (2020) DAMPAK CORONA TERHADAP UMKM naik kelas terjadi pada UMKM yang jeli membaca potensi pasar dan melakukan inovasi produk misalnya jamu dan produk herbal lainnya termasuk Masker.

" Bisa juga dibilang "gara-gara virus corona, UKM Produsen Jamu makin berkah" yang saat ini produk herbal yang berkaitan dengan pemeliharaan kesehatan seperti jahe merah sedang menikngkat permintaannya dipasaran . Seperti halnya di Semarang, jamu dibuat para pelaku UMKM dibawah binaan Dinas Koperasi dan UMKM Kota Semarang, dan menjadi dukungan bagi tenaga medis untuk menjaga kesehatannya dan sejumlah warga dengan kelompok ekonomi rentan melalui Puskesmas disetiap kecamatan dan kantor kelurahan. Dan di Banyuwangi pesanan minuman rempah meningkat 300\% dari 50 kotak perhari sampai menjadi 150 kotak perhari, terutama minuman jahe rempah celup, temulawak celup, minuman temulawak, sirup temulawak, ekstrak temulawak dan olahan jakuser yaitu jahe, kunyit dan serai. Pesanan minuman itu datang dari berbagai daerah mulai dari Surabaya, Jember, Yogyakarta, Tuban hingga ke Batam, masyarakat percaya minuman rempah dapat menjaga daya tahan tubuh dan terhindar dari virus covid-19 sehingga penjualan minuman rempah ini mendapatkan omset dan keuntungan lebih dari biasanya (18). Harapan kita semua bahwa jamu semakin diminati bagi masyrakat Indonesia sebagai upaya melestarikan warisan budaya bangsa'tegasnya.

e. Penggunaan SDM dari kalangan Generasi Z dan Milenials

Tentu saja tidak muda bagi generasi $\mathrm{Y}$ dan generasi yang lebih sepuh untuk beradaftasi dengan kemajuan tehnolog baru.Pada saat itulah UMKM yang progresif akan merekrut tenaga kerja dari kalangan milenial sebagai staf atau mitra reseller untuk melayani konsumen yang umumnya di masa covid ingin serba on line.

\section{KESIMPULAN}

Berdasarkan hasil penelitian di atas dalam dapat disimpulkan bahwa:

1. Faktor penyebab UMKM di masa normal dengan masa covid tidak jauh berbeda yaitu tergantung pada kompetensi kewirausahaan pemilik dan SDM dari karyawan. Agar UMKM sukses di masa pandemic covid 19 yang bersamaan dengan era pandemic covid 19 dan juga era revolusi Industri 4.0, UMKM harus berbenah diri baik internal maupun eksternal. Secara internal UMKM harus memperbaiki mindsetnya tentang makna berbisnis dari sekedar mendapatkan uang dan bekerja menjadi memimpin orang lain untuk mencapai tujuan pemberian pelayanan berkualitas bagi konsumen. Secara khusus terkait covid 19 
UMKM harus memahami dan menerapkan protocol covid 19 termasuk harus menjaga kebersihan menggunakan masker serta terampil melayani konsumen secara on line.

2. Faktor determinan dari pada penyebab UMKM Naik kelas dimasa pandemic covid 19 adalah kecepatan UMKM untuk memahami perubahan perilaku konsumen yang lebih senang dilayani secara on line, sesuai protocol kesehatan dan pembayaran yang lebih fleksibel. Selain itu perusahaan juga harus terampil membaca trend perubahan kebutuhan konsumen dan melakuan inovasi produk untuk memenuhi kebutuhan konsumen tersebut antara lain dapat dilaukan dengan penerapan tehnologi digital marketing, inovasi produk, pelayanan sesuai kesehatan dan protocol covid dan juga inovasi produk berbahan herbal serta trend UMKM dari kalangan generasi alpha $\mathrm{Z}$.

\section{DAFTAR PUSTAKA}

Aknolt Kristian Pakpahan. (2020). Covid-19 Dan Implikasi Bagi Usaha Mikro, Kecil, Dan Menengah, Jurnal Ilmiah Hubungan Internasional.

Brad Sugars. (2017). Jalur Cepat Menjadi Kaya - Jakarta,BIP Kelompok Gramedia

DH. Ismail (2010). Etos bisnis tiada merugi peta jalan menjadi pengusaha sukses dan Kaya. Jakarta: Penerbit Khalifa

Dingot Hamonangan Ismail Administrasi (2016). Strategi Mewujudkan Suatu Organisasi Pembelajar, JURNAL LENTERA BISNIS VOL. 5 NO. 1, Mei 2016 / ISSN 2252-9993

Euis Winarti, D. Purnomo, Jaenudin (2019), Analisis Faktor-Faktor Yang Mempengaruhi Di Perkampungan Industri Kecil ( PIK) Pulogadung Jakarta Timur, Jurnal Lentera Bisnis DOI : 10.34127/jrlab.v8i2.319, Volume 8, No 2 November 2019 ISSN Cetak 2252-9993, ISSN Online 2598-618X

Micro Mentor Indonesia (2020). Kumpulan Tips Praktis Untuk Umkm Beradaptasi Dalam Merespon Dampak Covid-19, Jakarta: Kementerian Koperasi dan Usaha Kecil dan Menengah, Republik Indonesia.

Ramaditya, Muhammad Effendi, Syahrul Faruqi, Faris Darmawan, Arya (2020), Pelatihan Kewirausahaan Kreatif Berbasis Manajemen Pemasaran Digital bagi UMKM Di Wilayah Rawamangun, Journal of Sustainable Community Development (JSCD)

Ratna, Aulia Fahmi, Idqan Hannan, Sufrin (2020), Digital Marketing Strategy of Small and Medium Enterprises for Snack in Bogor City. Jurnal Manajemen dan Agribisnis

Ratna Maulidiyah, Siti Saroh, Ratna Niken Hardati (2020), Pengaruh modal, sumber daya manusia, e- commerce, dan standarisasi produk terhadap daya saing, JIAGABI Vol. 9, No. 2, Agustus 2020, Hal. 358-368, ISSN:2302-7150

Santoso, Didik Haryadi, Awan Editor (2020). Covid -19 Dalam Ragam Tinjauan Presfektif, MBridge Press Jl. Ringroad Utara, Condong Catur, Depok, Kabupaten Sleman, D.I. Yogyakarta 
Seminar Nasional Penelitian dan Pengabdian kepada Masyarakat Universitas Sang Bumi Ruwa Jurai Tahun 2020

Saprianto, Febi (2020), Dilematis Umkm Di Era Digital, SCIENTIFIC JOURNAL OF REFLECTION : Economic, Accounting, Management and Business, DOI: 10.37481/sjr.v3i1.122

Wilantara, Rio. F, Indrawan, Ruly (2016). Serambinews.com,://aceh.tribunnews.com/2013/03/07/pengembangan-umkms 